\title{
EVALUASI PRESTASI BELAJAR MAHASISWA PROGRAM KELANJUTAN STUDI JURUSAN PENDIDIKAN AKUNTANSI DITINJAU DARI IPK D3 DAN ASAL PERGURUAN TINGGI
}

\author{
Oleh \\ M. Djazari ${ }^{1}$ \\ Endra Murti Sagoro ${ }^{2}$
}

\begin{abstract}
This research examines the difference of students learn performance of cognitive domain pursuant to "IPK D3", students learn performance of cognitive domain pursuant to come from college, students learn performance of affective domain pursuant to "IPK D3", students learn performance of affective domain pursuant to come from college, students learn performance of psychomotor domain pursuant to "IPK D3", students learn performance of psychomotor domain pursuant to come from college.

The subject of this research are 53 respondents. The data were collected by using questionnaires and documentation method. The validity of instrument was tested by implementing construct validity. From computation, one item from learn performance of affective domain was not valid and all items from learn of psychomotor domain was valid. The reliability of instrument was tested by implementing the Cronbach Alpha. From computational, instrument of learn performance of affective domain and psychomotor domain was valid.

The test of hypothesis will used Kruskal-Wallis test and Mann-Whitney test. The result of the research indicate: (1) there is significantly difference for learning performance of cognitive domain pursuant to "IPK D3", (2) there is not significantly difference for learning performance of cognitive domain pursuant to come from college, (3) there is not significantly difference for learning performance of affective domain pursuant to "IPK D3", (4) there is not significantly difference for learning performance of affective domain pursuant to come from college, (5) there is not significantly difference for learning performance of psychomotor domain pursuant to "IPK D3, and (6) there is not significantly difference for learning performance of psychomotor domain pursuant to come from college.
\end{abstract}

Keyword: cognitive domain, affective domain, psychomotor domain

\section{Latar Belakang Penelitian}

Perguruan tinggi merupakan tempat untuk mencetak individu-individu yang siap untuk bekerja. Proses belajar mengajar (PBM) di perguruan tinggi sangat menentukan kualitas lulusan yang dihasilkan oleh perguruan tinggi itu. Proses belajar mengajar yang bermutu tinggi akan menghasilkan lulusan yang bermutu, sebaliknya jika mutu PBM rendah akan mengakibatkan kualitas lulusan pun rendah pula. Meskipun diakui bahwa PBM hanyalah salah satu faktor saja yang menentukan kualitas lulusan, namun faktor PBM ini menempati urutan utama. Faktor lain yang sangat menentukan selain PBM adalah kualitas input mahasiswa. Semakin tinggi kualitas input, maka dapat diharapkan kualitas lulusan juga akan

\footnotetext{
${ }^{1}$ Dosen Jurusan Pendidikan Akuntansi - Universitas Negeri Yogyakarta

${ }^{2}$ Dosen Jurusan Pendidikan Akuntansi - Universitas Negeri Yogyakarta
} 
semakin baik. Sangat sulit menghasilkan lulusan yang bermutu baik, jika mutu inputnya kurang baik. Perbedaan kemampuan tiap individu dapat mempengaruhi hasil akhir dari suatu proses pembelajaran. Hal ini berarti bahwa faktor individu memiliki peranan penting yang menentukan kualitas lulusan suatu perguruan tinggi.

Dua hal di atas merupakan dua faktor penting yang mempengaruhi kualitas lulusan. Pertanyaannya adalah mana yang lebih penting? Jika jawabannya adalah proses pembelajaran, maka kualitas pembelajaran pada masing-masing perguruan tinggi akan menentukan kualitas lulusan. Proses pembelajaran yang baik akan memunculkan lulusan yang baik, harapannya adalah dengan kualitas input yang tinggi maupun rendah dapat lulus dari perguruan tinggi tersebut dengan kualitas yang baik. Perbedaan kualitas pembelajaran akan membedakan kualitas perguruan tinggi secara menyeluruh sehingga banyak masyarakat yang memilih perguruan tinggi tertentu agar mereka dapat menjadi individu yang lebih berkualitas. Namun, pertanyaan mendasar adalah apakah jika ada input mahasiswa "bodoh" masuk ke dalam perguruan tinggi tersebut, dia juga bisa setara dengan input mahasiswa "pintar"? Sebaliknya, jika jawabannya adalah kualitas input maka tinggi rendahnya input akan menentukan kualitas lulusan suatu perguruan tinggi. Input yang tinggi tentunya akan menjadi lulusan yang berkualitas, sedangkan input yang rendah akan menjadi lulusan yang tidak berkualitas. Hal ini berarti dengan input yang tinggi, setiap perguruan tinggi manapun dapat memunculkan lulusan berkualitas. Pertanyaan mendasar adalah apakah input yang tinggi akan tetap memiliki kualitas tinggi jika belajar di perguruan tinggi yang memiliki kualitas rendah? Dilihat dari dua faktor tersebut, faktor apakah yang lebih mempengaruhi kualitas lulusan suatu perguruan tinggi? Adakah perbedaan prestasi belajar mahasiswa jika dilihat dari kemampuan individu dan asal perguruan tinggi?

Jurusan Pendidikan Akutansi Universitas Negeri Yogyakarta (UNY) merupakan salah satu jurusan yang membuka Program Kelanjutan Studi (PKS), yaitu program yang dikhususkan bagi mahasiswa lulusan Diploma 3 (D3) yang ingin melanjutkan studi dan menempuh tingkat Starata 1 (S1). Universitas Negeri Yogyakarta memiliki tujuan agar dapat mencetak lulusan dengan kualitas terbaik di tiap bidangnya, tak terkecuali akuntansi. Pendidikan Akuntansi merupakan jurusan dengan mata kuliah teori dan praktik menuntut mahasiswa untuk terlibat aktif dalam proses pembelajarannya. Dengan adanya Program Kelanjutan Studi, apakah jurusan Pendidikan Akuntansi UNY dapat mencetak lulusan terbaik? Kembali pada pertanyaan di muka, kualitas lulusan akankah ditentukan oleh kualitas input atau kualitas pembelajaran di UNY?

Program Kelanjutan Studi hanya menerima mahasiswa yang telah berhasil menyelesaikan program D3 dari berbagai perguruan tinggi, termasuk UNY. Dengan input yang berasal dari perguruan tinggi, tentunya mahasiswa ini merupakan output dari masingmasing perguruan tinggi tersebut. Mahasiswa PKS merupakan mahasiswa yang telah mengalami proses pembelajaran dari perguruan tinggi yang berbeda-beda. Kemampuan awal dan kualitas tiap mahasiswa yang menempuh kuliah pada Program Kelanjutan Studi juga berbeda. Hal tersebut tentunya merupakan konsekuensi logis dari apa yang telah mereka dapatkan di perguruan tinggi sebelumnya. Perbedaan kemampuan dan kualitas mahasiswa akan menentukan prestasi belajar mahasiswa PKS.

Prestasi belajar merupakan hasil yang telah dicapai mahasiswa selama mengikuti proses pembelajaran. Prestasi belajar tersebut ditinjau dari ranah kognitif, afektif, dan psikomotorik. Beberapa permasalahan yang dihadapi dan berusaha diperoleh solusinya melalui penelitian ini diantaranya terkait dengan prestasi belajar mahasiswa PKS ditinjau dari kemampuan dari masing-masing mahasiswa itu sendiri (IPK D3) dan asal perguruan tinggi (PTN atau PTS). Tujuan penelitian ini adalah untuk mengetahui adakah perbedaan prestasi belajar dalam ranah kognitif, afektif, dan psikomotorik pada mahasiswa Program Kelanjutan Studi Jurusan Pendidikan Akuntansi ditinjau dari IPK D3 dan Asal Perguruan Tinggi. 


\subsection{Pengertian Prestasi Belajar}

\section{Telaah Literatur dan Pengembangan Hipotesis}

Prestasi belajar merupakan hal yang tidak dapat dipisahkan dari kegiatan belajar, karena kegiatan belajar merupakan proses, sedangkan prestasi merupakan hasil dari proses belajar. Memahami pengertian prestasi belajar secara garis besar harus bertitik tolak kepada pengertian belajar itu sendiri. Untuk itu para ahli mengemukakan pendapatnya yang berbedabeda sesuai dengan pandangan yang mereka anut. Namun, dari pendapat yang berbeda itu dapat kita temukan satu titik persamaan. Poerwanto (1986: 28) memberikan pengertian prestasi belajar merupakan "hasil yang dicapai oleh seseorang dalam usaha belajar sebagaimana yang dinyatakan dalam raport." Winkel (1996: 226) mengemukakan bahwa prestasi belajar merupakan bukti keberhasilan yang telah dicapai oleh seseorang. Maka prestasi belajar merupakan hasil maksimum yang dicapai oleh seseorang setelah melaksanakan usaha-usaha belajar. Sedangkan menurut Arif Gunarso (1993: 77) mengemukakan bahwa prestasi belajar adalah usaha maksimal yang dicapai oleh seseorang setelah melaksanakan usaha-usaha belajar. Menurut S. Nasution (1996: 17) prestasi belajar adalah: "Kesempurnaan yang dicapai seseorang dalam berfikir, merasa, dan berbuat. Prestasi belajar dikatakan sempurna apabila memenuhi tiga aspek yakni: kognitif, afektif dan psikomotorik, sebaliknya dikatakan prestasi kurang memuaskan jika seseorang belum mampu memenuhi target dalam ketiga kriteria tersebut."

Prestasi belajar di bidang pendidikan akuntansi adalah hasil dari pengukuran terhadap mahasiswa akuntansi yang meliputi faktor kognitif, afektif, dan psikomotorik setelah mengikuti proses pembelajaran yang diukur dengan menggunakan instrumen tes atau instrumen yang relevan. Jadi prestasi belajar adalah hasil pengukuran dari penilaian usaha belajar yang dinyatakan dalam bentuk simbol, huruf maupun kalimat yang menceritakan hasil yang sudah dicapai oleh setiap mahasiswa pada perioda tertentu. Perbedaan prestasi belajar dipengaruhi oleh beberapa faktor, yaitu faktor intern dan faktor ekstern.

Menurut Slameto (2003: 54) faktor-faktor yang mempengaruhi prestasi dapat digolongkan ke dalam dua golongan yaitu faktor intern yang bersumber pada diri siswa dan faktor ekstern yang bersumber dari luar diri siswa. Faktor intern terdiri dari kecerdasan atau intelegensi, perhatian, bakat, minat, motivasi, kematangan, kesiapan dan kelelahan. Faktor ekstern terdiri dari lingkungan keluarga, lingkungan sekolah, dan lingkungan masyarakat. Dalam penelitian ini, faktor intern dapat dilihat dari IPK D3 pada tiap-tiap mahasiswa yang dapat mencerminkan kemampuan mahasiswa dari sisi intern. Sedangkan faktor ekstern diproksikan dengan asal perguruan tinggi.

\subsection{Ranah Penilaian Kognitif}

Ranah kognitif adalah ranah yang mencakup kegiatan mental (otak). Menurut Bloom, segala upaya yang menyangkut aktivitas otak adalah termasuk dalam ranah kognitif. Ranah kognitif berhubungan dengan kemampuan berfikir, termasuk didalamnya kemampuan menghafal, memahami, mengaplikasi, menganalisis, mensintesis, dan kemampuan mengevaluasi. Dalam ranah kognitif itu terdapat enam aspek atau jenjang proses berfikir, mulai dari jenjang terendah sampai dengan jenjang yang paling tinggi. Keenam jenjang atau aspek yang dimaksud adalah:

1. Pengetahuan/hafalan/ingatan (knowledge), yaitu kemampuan seseorang untuk mengingat-ingat kembali (recall) atau mengenali kembali tentang nama, istilah, ide, rumus-rumus, dan sebagainya, tanpa mengharapkan kemampuan untuk 
menggunakannya. Pengetahuan atau ingatan adalah merupakan proses berfikir yang paling rendah.

2. Pemahaman (comprehension), yaitu kemampuan seseorang untuk mengerti atau memahami sesuatu setelah sesuatu itu diketahui dan diingat. Dengan kata lain, memahami adalah mengetahui tentang sesuatu dan dapat melihatnya dari berbagai segi. Seseorang dikatakan memahami sesuatu apabila ia dapat memberikan penjelasan rinci tentang hal itu dengan menggunakan kata-katanya sendiri. Pemahaman merupakan jenjang kemampuan berfikir yang setingkat lebih tinggi dari ingatan atau hafalan.

3. Penerapan (application), yaitu kesanggupan seseorang untuk menerapkan atau menggunakan ide-ide umum, tata cara ataupun metoda-metoda, prinsip-prinsip, rumusrumus, teori-teori dan sebagainya, dalam situasi yang baru dan kongkret. Penerapan ini adalah merupakan proses berfikir setingkat lebih tinggi ketimbang pemahaman. Salah satu contoh hasil belajar kognitif jenjang penerapan misalnya: Peserta didik mampu memikirkan tentang penerapan konsep akuntansi dalam kehidupan sehari-hari.

4. Analisis (analysis), yaitu kemampuan seseorang untuk merinci atau menguraikan suatu bahan atau keadaan menurut bagian-bagian yang lebih kecil dan mampu memahami hubungan di antara bagian-bagian atau faktor-faktor yang satu dengan faktor-faktor lainnya. Jenjang analisis adalah setingkat lebih tinggi daripada jenjang aplikasi.

5. Sintesis (syntesis), yaitu kemampuan berfikir yang merupakan kebalikan dari proses berfikir analisis. Sisntesis merupakan suatu proses yang memadukan bagian-bagian atau unsur-unsur secara logis, sehingga menjelma menjadi suatu pola yang yang berstruktur atau bebrbentuk pola baru. Jenjang sintesis kedudukannya setingkat lebih tinggi daripada jenjang analisis. Salah satu jasil belajar kognitif dari jenjang sintesis ini adalah: peserta didik dapat menulis karangan tentang pentingnya kedisiplinan.

6. Penilaian/penghargaan/evaluasi (evaluation), yaitu merupakan jenjang berpikir paling tinggi dalam ranah kognitif dalam taksonomi Bloom. Penilian/evaluasi disini merupakan kemampuan seseorang untuk membuat pertimbangan terhadap suatu kondisi, nilai atau ide, misalkan jika seseorang dihadapkan pada beberapa pilihan maka ia akan mampu memilih satu pilihan yang terbaik sesuai dengan patokan-patokan atau kriteria yang ada.

Tujuan aspek kognitif berorientasi pada kemampuan berfikir yang mencakup kemampuan intelektual yang lebih sederhana, yaitu mengingat, sampai pada kemampuan memecahkan masalah yang menuntut siswa untuk menghubungakan dan menggabungkan beberapa ide, gagasan, metoda atau prosedur yang dipelajari untuk memecahkan masalah tersebut. Dengan demikian aspek kognitif adalah subtaksonomi yang mengungkapkan tentang kegiatan mental yang sering berawal dari tingkat pengetahuan sampai ke tingkat yang paling tinggi yaitu evaluasi. Dalam ranah kognitif ini, faktor intern dari tiap-tiap mahasiswa sangat berpengaruh. Kemampuan berpikir untuk mengetahui, memahami, dan mengevaluasi masingmasing mahasiswa jelas berbeda. Namun, untuk faktor ekstern, dapat dibuat situasi yang sama sehingga memungkinkan kemampuan kognitif mahasiswa sama.

Berdasarkan penjelasan tersebut, maka hipotesis yang dapat diajukan adalah sebagai berikut.

Hipotesis 1a: Terdapat perbedaan Prestasi Belajar Kognitif mahasiswa PKS ditinjau dari IPK D3.

Hipotesis 1b: Tidak terdapat perbedaan Prestasi Belajar Kognitif mahasiswa PKS ditinjau dari Asal Perguruan Tinggi.

\subsection{Ranah Penilaian Afektif}

Ranah afektif adalah ranah yang berkaitan dengan sikap dan nilai. Ranah afektif mencakup watak perilaku seperti perasaan, minat, sikap, emosi, dan nilai. Beberapa pakar mengatakan bahwa sikap seseorang dapat diramalkan perubahannya bila seseorang telah memiliki kekuasaan kognitif tingkat tinggi. Ciri-ciri hasil belajar afektif akan tampak pada 
peserta didik dalam berbagai tingkah laku. Seperti perhatiannya terhadap mata kuliah akuntansi, kedisiplinannya dalam mengikuti mata kuliah di kampus, motivasinya yang tinggi untuk tahu lebih banyak mengenai akuntansi, penghargaan atau rasa hormatnya terhadap dosen akuntansi, dan sebagainya.

Menurut Krathwohl (1961) tingkatan ranah ada lima,yaitu: receiving, responding, valuing, organization, dan characterization by evalue or calue complex.

1. Receiving atau attenting (menerima atau memperhatikan), adalah kepekaan seseorang dalam menerima rangsangan (stimulus) dari luar yang datang kepada dirinya dalam bentuk masalah, situasi, gejala dan lain-lain. Termasuk dalam jenjang ini misalnya adalah: kesadaran dan keinginan untuk menerima stimulus, mengontrol dan menyeleksi gejala-gejala atau rangsangan yang datang dari luar. Receiving atau attenting juga sering diberi pengertian sebagai kemauan untuk memperhatikan suatu kegiatan atau suatu objek. Pada jenjang ini peserta didik dibina agar mereka bersedia menerima nilai atau nilai-nilai yang di ajarkan kepada mereka, dan mereka mau menggabungkan diri ke dalam nilai itu atau mengidentifikasikan diri dengan nilai itu.

2. Responding (menanggapi) mengandung arti "adanya partisipasi aktif". Jadi kemampuan menanggapi adalah kemampuan yang dimiliki oleh seseorang untuk mengikut sertakan dirinya secara aktif dalam fenomena tertentu dan membuat reaksi terhadapnya salah satu cara.

3. Valuing (menilai atau menghargai). Menilai atau menghargai artinya mem-berikan nilai atau memberikan penghargaan terhadap suatu kegiatan atau obyek, sehingga apabila kegiatan itu tidak dikerjakan, dirasakan akan membawa kerugian atau penyesalan. Valuing adalah merupakan tingkat afektif yang lebih tinggi lagi daripada receiving dan responding. Dalam kaitan dalam proses belajar mengajar, peserta didik disini tidak hanya mau menerima nilai yang diajarkan tetapi mereka telah berkemampuan untuk menilai konsep atau fenomena, yaitu baik atau buruk. Bila suatu ajaran yang telah mampu mereka nilai dan mampu untuk mengatakan "itu adalah baik", maka ini berarti bahwa peserta didik telah menjalani proses penilaian. Nilai itu mulai dicamkan (internalized) dalam dirinya. Dengan demikian nilai tersebut telah stabil dalam peserta didik.

4. Organization (mengatur atau mengorganisasikan), artinya memper-temukan perbedaan nilai sehingga terbentuk nilai baru yang universal, yang membawa pada perbaikan umum. Mengatur atau mengorganisasikan merupakan pengembangan dari nilai kedalam satu sistem organisasi, termasuk didalamnya hubungan satu nilai denagan nilai lain, pemantapan dan perioritas nilai yang telah dimilikinya.

5. Characterization by evalue or calue complex (karakterisasi dengan suatu nilai atau komplek nilai), yakni keterpaduan semua sistem nilai yang telah dimiliki oleh seseorang, yang mempengaruhi pola kepribadian dan tingkah lakunya. Di sini proses internalisasi nilai telah menempati tempat tertinggi dalal suatu hirarki nilai. Nilai itu telah tertanam secara konsisten pada sistemnya dan telah mempengaruhi emosinya. Ini adalah merupakan tingkat afektif tertinggi, karena sikap batin peserta didik telah benar-benar bijaksana. Jadi pada jenjang ini peserta didik telah memiliki sistem nilai yang telah mengontrol tingkah lakunya untuk suatu waktu yang lama, sehingga membentuk karakteristik "pola hidup" tingkah lakunya menetap, konsisten dan dapat diramalkan.

Skala yang digunakan untuk mengukur ranah afektif seseorang terhadap kegiatan suatu objek diantaranya skala sikap. Hasilnya berupa kategori sikap, yakni mendukung (positif), menolak (negatif), dan netral. Sikap pada hakikatnya adalah kecenderungan berperilaku pada seseorang. Tinggi rendahnya nilai afektif dari tiap mahasiswa dipengaruhi oleh faktor intern dan ekstern dari seseorang. Dalam ranah afektif ini, faktor intern dari tiap-tiap mahasiswa akan mempengaruhi sikap mereka, karena pada dasarnya nilai afektif dipengaruhi oleh pribadi masing-masing mahasiswa, sehingga akan menimbulkan perbedaan nilai afektif pada 
tiap-tiap mahasiswa. Namun, untuk faktor ekstern, dapat dibuat situasi yang sama sehingga memungkinkan nilai afektif mahasiswa sama.

Berdasarkan penjelasan tersebut, maka hipotesis yang dapat diajukan adalah sebagai berikut.

Hipotesis 2a: Terdapat perbedaan Prestasi Belajar Afektif mahasiswa PKS ditinjau dari IPK D3.

Hipotesis 2b: Tidak terdapat perbedaan Prestasi Belajar Afektif mahasiswa PKS ditinjau dari Asal Perguruan Tinggi.

\subsection{Pengertian Ranah Penilaian Psikomotorik}

Bloom (1979) berpendapat bahwa ranah psikomotor berhubungan dengan hasil belajar yang pencapaiannya melalui keterampilan manipulasi yang melibatkan otot dan kekuatan fisik. Singer (1972) menambahkan bahwa mata kuliah yang berkaitan dengan psikomotor adalah mata kuliah yang lebih beorientasi pada gerakan dan menekankan pada reaksi-reaksi fisik dan keterampilan tangan. Keterampilan itu sendiri menunjukkan tingkat keahlian seseorang dalam suatu tugas atau sekumpulan tugas tertentu. Dalam mata kuliah akuntansi, terdapat juga ranah psikomotorik, yaitu ketika mahasiswa mengerjakan tugas praktek akuntansi yang menuntut mereka untuk tidak hanya menggunakan kemampuan kognitif mereka tetapi juga menggunakan kemampuan psikomotorik. Kecepatan dan kecakapan dalam mengerjakan praktik akuntansi ditentukan juga oleh kemampuan psikomotorik mahasiswa.

Hasil belajar ranah psikomotor dikemukakan oleh Simpson (1956) yang menyatakan bahwa hasil belajar psikomotor ini tampak dalam bentuk keterampilan dan kemampuan bertindak individu. Hasil belajar psikomotor sebenarnya merupakan kelanjutan dari hasil belajar kognitif (memahami sesuatu) dan hasil belajar afektif (yang baru tampak dalam bentuk kecenderungan-kecenderungan berperilaku).

Ada beberapa ahli yang menjelaskan cara menilai hasil belajar psikomotor. Ryan (1980) menjelaskan bahwa hasil belajar keterampilan dapat diukur melalui (1) pengamatan langsung dan penilaian tingkah laku peserta didik selama proses pembelajaran praktik berlangsung, (2) sesudah mengikuti pembelajaran, yaitu dengan jalan memberikan tes kepada peserta didik untuk mengukur pengetahuan, keterampilan, dan sikap, (3) beberapa waktu sesudah pembelajaran selesai dan kelak dalam lingkungan kerjanya. Sementara itu Leighbody (1968) berpendapat bahwa penilaian hasil belajar psikomotor mencakup: (1) kemampuan menggunakan alat dan sikap kerja, (2) kemampuan menganalisis suatu pekerjaan dan menyusun urut-urutan pengerjaan, (3) kecepatan mengerjakan tugas, (4) kemampuan membaca gambar dan atau simbol, (5) keserasian bentuk dengan yang diharapkan dan atau ukuran yang telah ditentukan.

Dari penjelasan di atas dapat dirangkum bahwa dalam penilaian hasil belajar psikomotor atau keterampilan harus mencakup persiapan, proses, dan produk yang dapat dinilai pada saat proses pembelajaran berlangsung atau sesudah proses berlangsung. Sama seperti kemampuan kognitif dan afektif, kemampuan psikomotorik dapat dipengaruhi oleh faktor intern dan ekstern. Kemampuan individu dan keadaan lingkungan kampus yang sengaja dibuat agar kemampuan psikomotorik mahasiswa sama akan mempengaruhi besar kecilnya nilai psikomotorik mahasiswa.

Berdasarkan penjelasan tersebut, maka hipotesis yang dapat diajukan adalah sebagai berikut.

Hipotesis 3a: Terdapat perbedaan Prestasi Belajar Psikomotorik mahasiswa PKS ditinjau dari IPK D3.

Hipotesis 3b: Tidak terdapat perbedaan Prestasi Belajar Psikomotorik mahasiswa PKS ditinjau dari Asal Perguruan Tinggi.

\subsection{Desain Penelitian}


Secara skematis, desain penelitian untuk menggambarkan alur permasalahan dan jawaban yang diharapkan serta model pengujiannya dapat digambar sebagai berikut.

\section{Sisipkan Gambar 2.1}

\subsection{Subyek Penelitian}

\section{Metoda Penelitian}

Untuk dapat memahami permasalahan yang diteliti sehingga lebih mendalam dan mendetail, maka subyek penelitian yang digunakan adalah seluruh mahasiswa Program Kelanjutan Studi Jurusan Pendidikan Akuntansi yang berasal dari program Diploma III dari berbagai perguruan tinggi. Subyek penelitian ini mencakup mahasiswa Program Studi Pendidikan Akuntansi dan Program Studi Akuntansi yang berjumlah 53 mahasiswa.

\subsection{Jenis Data dan Teknik Pengumpulan Data}

Data penelitian didapatkan dari IPK mahasiswa dan kuesioner yang disebarkan kepada mahasiswa. Pengumpulan data menggunakan dokumentasi dan kuesioner. Dokumentasi digunakan untuk mengetahui kemampuan mahasiswa dari ranah kognitif (IPK D3 dan S1) dan Asal Perguruan Tinggi (PTN atau PTS). Sedangkan kuesioner digunakan untuk mengetahui kemampuan mahasiswa dari ranah afektif dan psikomotorik. Kuesioner menggunakan modifikasi skala Likert. Hasil kuisioner dalam penelitian ini merupakan data ordinal sehingga pengujian yang digunakan adalah non parametrik.

\subsection{Definisi Operasional dan Pengukuran Variabel}

Untuk memberikan pemahaman yang lebih spesifik terhadap variabel penelitian, maka variabel-variabel tersebut didefinisikan secara operasional sebagai berikut:

1. Prestasi Belajar Kognitif adalah kemampuan mahasiswa untuk berpikir yang mencakup kemampuan intelektual, yaitu mengingat sampai pada kemampuan memecahkan masalah yang menuntut mahasiswa untuk menghubungakan dan menggabungkan beberapa ide, gagasan, metoda atau prosedur yang dipelajari untuk memecahkan masalah tersebut. Variabel ini diukur dengan menggunakan Indek Prestasi Kumulatif S1 masing-masing mahasiswa yang kemudian dikategorikan menjadi sangat tinggi, tinggi, sedang, dan rendah.

2. Prestasi Belajar Afektif adalah hasil belajar yang menunjukkan perilaku atau sikap mahasiswa yang mengarah positif seperti minat tinggi, disiplin tinggi, motivasi tinggi, rasa hormat tinggi, dan sebagainya. Variabel ini diukur dengan menggunakan kuesioner yang terdiri dari lima indikator yaitu sikap, minat, konsep diri, nilai, dan moral. Hasil dari kuesioner kemudian dikategorikan menjadi sangat tinggi, tinggi, sedang, dan rendah.

3. Prestasi Belajar Psikomotorik adalah hasil belajar yang tampak dalam bentuk keterampilan dan kemampuan bertindak individu dalam mengerjakan tugas-tugas akuntansi. Variabel ini diukur dengan menggunakan kuesioner yang terdiri dari lima indikator yaitu kemampuan menggunakan alat, menganalisis pekerjaan, kecepatan mengerjakan tugas, kemampuan menerjemahkan, dan kesesuaian pelaksanaan tugas. Hasil dari kuesioner kemudian dikategorikan menjadi sangat tinggi, tinggi, sedang, dan rendah.

\subsection{Teknik Analisis Data}

Berdasarkan pada hipotesis yang diajukan, maka teknik analisis yang digunakan adalah uji beda Kruskal-Wallis untuk hipotesis H1a, H2a, dan H3a dan digunakan uji beda MannWhitney untuk hipotesis $\mathrm{H} 1 \mathrm{~b}, \mathrm{H} 2 \mathrm{~b}$, dan $\mathrm{H} 3 \mathrm{~b}$. Sebelum dilakukan uji beda dilakukan pengujian validitas dan reliabilitas pada item-item pernyataan khususnya untuk mengukur Prestasi Belajar Afektif dan Prestasi Belajar Psikomotorik.

\section{Hasil Penelitian dan Pembahasan}




\subsection{Hasil Pengujian Validitas dan Reliabilitas}

Pengujian yang dilakukan dalam penelitian ini berupa uji beda dengan alat uji KruskalWallis dan Mann-Whitney. Sebelum dilakukan uji beda, dilakukan uji validitas dan reliabilitas. Uji validitas dilakukan dengan menggunakan korelasi antar skor masing-masing butir pernyataan dengan skor total. Hasil pengujian dengan Pearson Corellation menunjukkan validitas pada skor masing-masing butir dengan skor totalnya untuk Prestasi Belajar Afektif dan Prestasi Belajar Psikomotorik. Untuk pengujian reliabilitas digunakan teknik Cronbach Alpha. Hasil pengujian menunjukkan data kuisioner adalah reliabel. Dengan kata lain, data kuisioner yang terdapat pada tabel 4.1 dan tabel 4.2 adalah valid dan reliabel.

\section{Sisipkan Tabel 4.1. dan Tabel 4.2.}

\subsection{Hasil Uji Beda Kruskal-Wallis dan Mann-Whitney}

Hasil uji beda dengan Kruskal-Wallis dan Mann-Whitney pada mahasiswa Jurusan Pendidikan Akuntansi mengenai prestasi Belajar Kognitif, Afektif, dan Psikomotorik ditinjau dari IPK D3 dan Asal Perguruan Tinggi dapat dilihat pada tabel 4.3.

\section{Sisipkan Tabel 4.3.}

Berdasarkan pada tabel tersebut dapat dilihat nilai signifikansi pada Prestasi Belajar Kognitif berdasarkan IPK D3 adalah 0,003. Nilai ini lebih kecil dari 0,05 yang menunjukkan bahwa Prestasi Belajar Kognitif mahasiswa berdasarkan IPK D3 adalah berbeda. Hasil ini mendukung hipotesis H1a. Hal ini dikarenakan Prestasi Belajar Kognitif mahasiswa (IPK S1) tentunya akan dipengaruhi IPK D3. Mahasiswa dengan IPK D3 tinggi, kemungkinan besar akan memiliki IPK S1 yang tinggi pula. Sebaliknya mahasiswa dengan IPK D3 rendah kemungkinan akan memiliki IPK S1 yang rendah.

Untuk Prestasi Belajar Kognitif berdasarkan asal PT memiliki nilai signifikansi sebesar 0,668. Nilai ini lebih besar dari 0,05 yang menunjukkan bahwa prestasi belajar kognitif mahasiswa berdasarkan asal PT adalah tidak berbeda. Hasil ini mendukung hipotesis H1b. Hal ini dikarenakan Prestasi Belajar Kognitif mahasiswa (IPK S1) tentunya akan dipengaruhi kemampuan bawaan masing-masing individu serta faktor-faktor intern lainnya sehingga asal perguruan tinggi secara statistis tidak berpengaruh signifikan terhadap Prestasi Belajar Kognitif mahasiswanya.

Untuk nilai signifikansi Prestasi Belajar Afektif berdasarkan IPK D3 adalah sebesar 0,319. Nilai ini lebih besar dari 0,05 yang menunjukkan bahwa Prestasi Belajar Afektif mahasiswa berdasarkan IPK D3 adalah tidak berbeda. Hasil ini tidak mendukung hipotesis H2a. Hal ini dikarenakan Prestasi Belajar Afektif mahasiswa tidak semata-mata dipengaruhi oleh kemampuan akademis mahasiswa tersebut. Tidak sedikit mahasiswa yang memiliki IPK tinggi mempunyai sikap yang tidak baik, begitu pula sebaliknya mahasiswa yang memiliki IPK rendah bisa mempunyai sikap yang lebih baik.

Untuk nilai signifikansi Prestasi Belajar Afektif berdasarkan asal PT adalah sebesar 0,397. Nilai ini lebih besar dari 0,05 yang menunjukkan bahwa Prestasi Belajar Afektif mahasiswa berdasarkan asal PT adalah tidak berbeda. Hasil ini mendukung hipotesis $\mathrm{H} 2 \mathrm{~b}$. Hal ini dikarenakan prestasi belajar afektif mahasiswa secara statistis tidak dipengaruhi oleh lingkungan di luar diri mahasiswa, contohnya adalah perguruan tinggi asal masing-masing mahasiswa tersebut. Sikap mahasiswa kemungkinan lebih dipengaruhi oleh dirinya masingmasing, walaupun dampak dari lingkungan sekitar juga dapat berpengaruh. Hal seperti motivasi dari dalam diri sendiri terasa lebih realistis untuk mempengaruhi sikap masingmasing mahasiswa.

Untuk nilai signifikansi Prestasi Belajar Psikomotorik berdasarkan IPK D3 adalah sebesar 0,720. Nilai ini lebih besar dari 0,05 yang menunjukkan bahwa Prestasi Belajar Psikomotorik mahasiswa berdasarkan IPK D3 adalah tidak berbeda. Hasil ini tidak mendukung hipotesis $\mathrm{H} 3 \mathrm{a}$. Hal ini dikarenakan prestasi belajar psikomotorik mahasiswa tidak hanya ditentukan oleh kemampuan akademis mahasiswa yang ditunjukkan dengan IPK D3. 
Keterampilan masing-masing mahasiswa pada dasarnya dapat dibuat sama dengan cara mengajarkan kepada mereka tentang bagimana menciptakan keterampilan tersebut. Mahasiswa yang memiliki IPK tinggi belum tentu memiliki keterampilan yang baik, sebaliknya mahasiswa dengan IPK rendah juga belum tentu keterampilannya buruk.

Untuk nilai signifikansi Prestasi Belajar Psikomotorik berdasarkan asal PT adalah sebesar 0,237. Nilai ini lebih besar dari 0,05 yang menunjukkan bahwa Prestasi Belajar Psikomotorik mahasiswa berdasarkan asal PT adalah tidak berbeda. Hasil ini mendukung hipotesis $\mathrm{H} 3 \mathrm{~b}$. Hal ini dikarenakan prestasi belajar psikomotorik mahasiswa dapat ditentukan oleh pembelajaran yang ada di perguruan tinggi ketika mahasiswa tersebut menempuh studi lanjutannya. Perguruan tinggi yang memiliki komitmen untuk meningkatkan keterampilan mahasiswanya akan menghasilkan mahasiswa dengan Prestasi Belajar Psikomotorik yang sama. Jadi, darimana pun asal PT mahasiswa tersebut, jika dalam kampus barunya memperoleh pendidikan psikomotorik yang sama, hasilnya akan sama.

\section{Diskusi}

Hasil penelitian menunjukkan bahwa prestasi belajar mahasiswa dari ranah kognitif, afektif, dan psikomotorik bisa berbeda atau tidak berbeda. Hal tersebut tentunya dipengaruhi oleh beberapa faktor, baik yang berasal dari intern maupun ekstern. Prestasi belajar kognitif lebih ditentukan oleh kemampuan akademis masing-masing mahasiswa. Hal ini ditunjukkan dengan adanya perbedaan prestasi belajar mahasiswa berdasarkan IPK D3nya. Sedangkan prestasi belajar afektif dari masing-masing mahasiswa dengan IPK D3 dan asal perguruan tinggi yang berbeda menunjukkan hasil yang sama. Hal ini menunjukkan bahwa IPK D3 dan asal perguruan tinggi tidak mempengaruhi sikap mahasiswa. Terakhir, prestasi belajar psikomotorik mahasiswa dari PT yang berbeda dan IPK berbeda ternyata tidak berbeda. Dari hasil tersebut, pertanyaan mendasar adalah apa yang lebih berpengaruh terhadap prestasi belajar mahasiswa secara keseluruhan? Apakah dengan input (kemampuan awal mahasiswa yang dilihat dari IPK D3) yang baik maka lulusan akan baik? Atau asal perguruan tinggi (PTN atau PTS) yang akan menentukan kualitas lulusan. Hal tersebut menjadi dua sisi yang cukup berlawanan. Artinya jika memilih yang pertama, yaitu prestasi belajar dipengaruhi oleh kemampuan mahasiswa, maka di manapun dia kuliah, maka prestasinya (IPK) tetap sama. Dengan catatan, pembelajaran pada masing-masing perguruan tinggi dibuat standar yang sama. Jadi, di manapun seseorang akan menempuh kuliah, kualitasnya sama. Sedangkan jika memilih alternatif yang kedua, yaitu prestasi belajar ditentukan oleh asal perguruan tinggi, maka dengan kemampuan seperti apapun jika kuliah di perguruan tinggi tersebut, maka prestasinya akan meningkat. Secara kasar, mahasiswa "bodoh" jika kuliah di perguruan tinggi tertentu maka dia akan lulus dengan hasil yang baik.

\section{Keterbatasan Penelitian}

Penelitian ini mempunyai beberapa keterbatasan atau kelemahan, yaitu subyek penelitian yang digunakan hanya berasal dari beberapa Perguruan Tinggi Negeri dan beberapa Perguruan Tinggi Swasta di Indonesia sehingga tidak bisa digeneralisasi secara nasional. Selain itu keterbatasan lainnya adalah prestasi belajar psikomotorik diukur dengan menggunakan kuesioner sehingga belum dapat terlihat keterampilan mahasiswa yang sesungguhnya jika melakukan tes yang sebenarnya sehingga nilai prestasi belajar psikomotorik hanya sebatas pendapat dari masing-masing responden mengenai prestasi belajar psikomotorik mereka sendiri. Hal ini dapat menyebabkan prestasi belajar psikomotorik belum terukur secara akurat.

\subsection{Kesimpulan}

\section{Kesimpulan dan Saran}

Berdasarkan hasil penelitian, maka kesimpulan penelitian ini adalah sebagai berikut: 
1. Prestasi belajar kognitif lebih ditentukan oleh kemampuan akademis masing-masing mahasiswa. Hal ini ditunjukkan dengan adanya perbedaan prestasi belajar mahasiswa berdasarkan IPK D3nya.

2. Prestasi belajar afektif mahasiswa berdasarkan IPK D3 dan Asal Perguruan Tinggi tidak berbeda. Hal ini menunjukkan bahwa IPK D3 dan Asal Perguruan Tinggi tidak mempengaruhi secara signifikan sikap mahasiswa.

3. Prestasi belajar psikomotorik mahasiswa dengan IPK D3 dan asal PT yang berbeda ternyata menunjukkan hasil yang sama. Hal ini berarti bahwa prestasi belajar psikomotorik mahasiswa tidak ditentukan oleh IPK D3 dan Asal Perguruan Tinggi.

4. Secara keseluruhan, prestasi belajar yang menunjukkan perbedaan secara statistis adalah prestasi belajar kognitif yang ditinjau dari kemampuan awal (IPK D3) tiap-tiap mahasiswa yang berarti bahwa kemampuan mahasiswa untuk mengetahui, memahami, menerapkan, menganalisis, dan mengevaluasi memang berbeda-beda.

\subsection{Saran}

Berdasarkan kesimpulan dalam penelitian ini, maka saran untuk penelitian selanjutnya adalah sebagai berikut:

1. Penelitian dilakukan dengan responden dari berbagai PTN dan PTS di seluruh Indonesia sehingga dapat digeneralisasi secara nasional.

2. Pengukuran prestasi belajar psikomotorik dilakukan dengan observasi langsung dan melakukan tes langsung.

3. Penelitian mempertimbangkan faktor lain selain IPK D3 dan asal PT sehingga akan didapatkan faktor-faktor penting yang dapat mempengaruhi prestasi belajar mahasiswa dalam ranah kognitif, afektif, dan psikomotorik.

\section{DAFTAR PUSTAKA}

Leighbody, G.B. (1968). Methods of teaching shop and technical subjects. New York: Delmar Publishing.

M. Ngalim Purwanto. (1986). Prinsip - Prinsip dan Teknik Evaluasi Pengajaran. Bandung: CV Remaja Karya.

Ryan, D.C. (1980). Characteristics of teacher. A Research study: Their description, comparation, and appraisal. Washington, DC: American Council of Education.

Saifudin Anwar. (2005). Belajar dan Pembelajaran. Jakarta : PT Bina Aksara.

Sardiman, A.M. (2005). Interaksi dan Motivasi Belajar Mengajar. Jakarta: Bina Aksara.

Slameto. (2003). Evaluasi Pendidikan. Jakarta: Bina Aksara.

S. Nasution. (1996). Berbagai Pendekatan dalam Proses Belajar dan Mengajar. Jakarta: Bumi Aksara.

Thursan Hakim. (2000). Belajar Secara Efektif. Depok: Puspa Swara.

Udin S. Winataputra, dkk. (1995). Buku Materi Pokok: Strategi Belajar Mengajar. Jakarta: Universitas Terbuka Departemen Pendidikan dan Kebudayaan.

Winkel, W.S. (1996). Bimbingan dan Konseling di Institusi Pendidikan. Jakarta: Gramedia. 